Shireen Samy Mohamed Ibrahim

\title{
A Corpus-Based Study of Further Fables for Our Time: An Ecolinguistic Perspective
}

\section{Shireen Samy Mohamed Ibrahim}

Demonstrator in Department of English - Faculty of Education - Ain Shams University.

\section{Abstract}

The research seeks to explore the representation of nature in fables, from an ecolinguistic perspective, taking Further Fables for Our Time as an example. The aims of the research are: 1) to explore the language patterns which are used to depict nature, e.g., the repetition of certain lexis; 2) to investigate the tendencies and attitudes found in these fables toward nature through examining whether they encourage respect and care for the ecosystems, or encourage ecological destruction; 3) to provide an ecolinguistic example by tracing the animals' relationships, how they treat the elements of nature, and how these relationships mirror human social relations and attitude towards nature. The research draws on ecolinguistics as a new perspective of looking at language, adopts one type of ecosophies categorized by Stibbe (2015), i.e. frames, relying on this theory in the analysis: Lakoff's frame theory. Besides, the researcher uses corpus linguistics as a tool to achieve the objectives of the thesis, depending on LancBox version 4.0. The data is comprised of 47 fables written by James Thurber collected from the internet in pdf form. The analysis shows the possibility of studying fables from an ecolinguistic perspective. As well, the conclusion elucidates that the interactions between animals, to a large extent, resemble human social relations and manner of exploiting nature.

Keywords: Ecolinguistics; Corpus; Fables; Further Fables for Our Time.

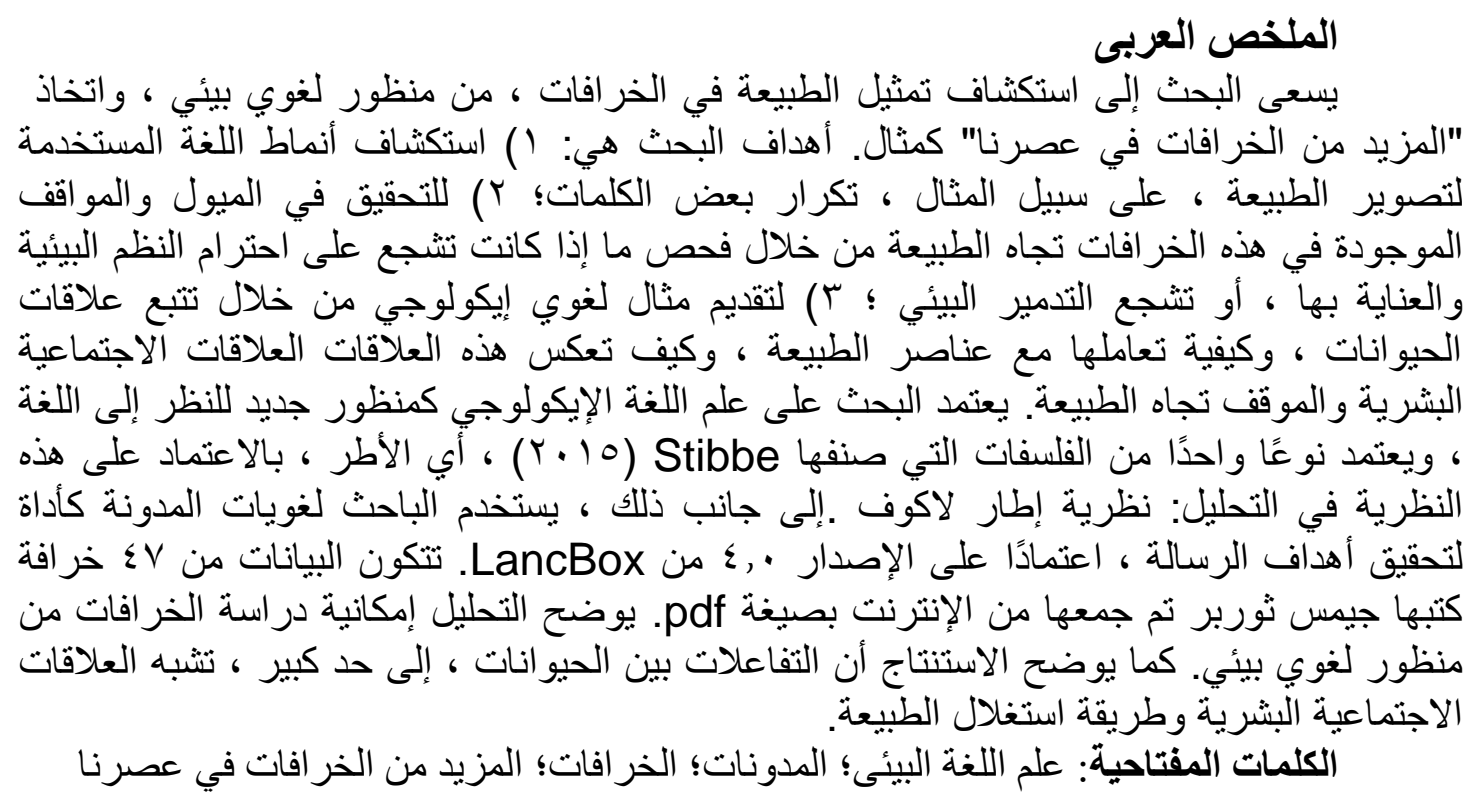




\section{Introduction}

Humans use language as a means to reflect their perception, ideas and beliefs about the outside world, and specifically about our environment. Thus, through language we either reduce the natural world mentally to objects or resources to be exploited, or respect and care for the systems that support life. Language plays a vital role in raising the awareness of people towards the issues of environment.

Ecolinguistics comprises two disciplines (linguistics and ecology). This new discipline is concerned with the ecological analysis of any discourse, whether this discourse is a signpost, a literary work, a text about environment, an advertisement, a conversation between friends, or a news report.

Einar Haugen is regarded as the founder of 'language ecology' or 'ecology of language'. It is worth noting that these two phrases are not opposed to each other but complement each other. Haugen highlights the need to focus on the ecological study of language and the linguistic study of ecology. In 1972, Haugen published a collection of his essays under the title "The ecology of language" (cited in Fill \& Muhlhausler, 2001, p.57).

In 1990 Halliday draws the attention to the importance of considering problems like "classism, destruction of species, pollution not only as biological and physical problems, but also as problems for the applied linguistic community" (cited in Fill \& Muhlhausler, 2001, p.199). He studies how the linguistic patterns "affect the survival and wellbeing of the human species as well as other species on earth" (Steffensen \& Fill, 2014, p.9).

Haugen uses the term "ecology" metaphorically in which language is treated as a living organism, and so he tends to focus on aspects like "language contact, language conflict, language death, language growth, language planning and language interference" (Fill, 1997, p.450). On the other hand, Halliday explains what role language, as a discourse, plays in the ecological and environmental domains.

Ecolinguistic analysis adopts a number of different philosophical frameworks. The philosophical framework is known as "Ecosophy" as Naess has called (cited in Wu, 2018, p.649). This ecosophy "is useful for describing frameworks that ecolinguistic studies use to judge discourses against" (cited in Wu, 2018, p.649). Each linguist may have his/her own philosophical basics, values, or priorities against which he judges the discourses. 


\section{Shireen Samy Mohamed Ibrahim}

Discourses can be divided into different modes. Each mode has its own linguistic characteristics or features. For example, a fable differs from a newspaper article, as it is short, depends on simple lexis, has its own language patterns, and has a didactic function. Fables are one of the most famous models of children's literature, which can be defined as "Short stories that teach a moral, or a lesson to children. The stories are often funny. The characters of fables are usually animals who act and talk like people but still have animals' traits" (Surber, n.d.).

Fables have become familiar in children's literature domain in which animals display different human characteristics or behaviours. Some writers use a literary device which is called anthropomorphism. Eugenio Bolongaro (2009) describes this anthropomorphism in fables as the attribution of human traits to animals. Aesop's Fables and Jean De La Fountain's Fables are regarded as the most popular ones. Fables can be considered as a means of entertainment, and a means of concealed criticism. In addition, this research studies fables as a means of exploring the representation of nature, drawing on ecolinguistic analysis. The focus on the way these fables portray the interaction between wild and domestic animals, how they reflect human social and political relations, how humans perceive the surrounding environment through animals' behaviours, and how human is represented are considered the most important concerns of ecolinguistic studies.

The lexical choices of the author can form patterns, which can convey a specific message, or serve a specific purpose. Repeating words or grammatical structures for impact, switching between opposing opinions to help the readers understand both sides, the repetition of specific theme, the way paragraphs begin throughout an essay or a book, or how a text is organized to emphasize the meaning are all forms of language patterns.

Corpus linguistics (CL) is "an approach or a methodology for studying language use" (Bowker \& Pearson, 2002, p.9). It is a collection or repository of texts stored in an electronic database. CL comprises both quantitative aspects and qualitative aspects. Corpora depend on some software tools that "allow users to search through them rapidly and reliably" (McEnery \& Hardie, 2012, p.2). These tools help the researcher in detecting the language patterns and analyzing them.

2. Objectives of the study:

1) To explore the language patterns which are used to depict nature, e.g. the repetition of certain nouns, and the repetition of specific themes or ideas that support the author's point of view. 
2) To investigate the tendencies and attitudes found in these fables towards nature through examining whether they encourage respect and care for the ecosystems that support life, or encourage ecological destruction, by highlighting the distinctive language patterns that the writer use.

3) To provide an ecolinguistic analysis by tracing how the animals treat each other, how the animals treat the surrounding elements of nature, how both (animals and humans) use nature, how human to other species is represented, and to draw an analogy between animal relations and human social relations.

3. Rationale of the study:

Ecological analysis started with the application of critical discourse analysis of texts about the environment and environmentalism in order to reveal hidden assumptions and messages, and to comment on the effectiveness of these in achieving environmental aims. It then developed to include analysis of any discourse which has potential consequences for the future of ecosystems (Ecolinguistics, n.d.).

Some studies discuss fables from a stylistic perspective through focusing on the authors' usage of the literary device anthropomorphism as an effective tool for creating political and social satires or for revealing some facts about human nature or traits, as illustrated above. Some other writers use fables to teach children moral lessons as it attracts the attention of the children.

This study considers fables from another perspective. The protagonists of the fables are usually non-human (animals or objects) who interact with each other, and interact with the elements of nature surrounding them. Through these interactions, fables give us a glimpse of how humans treat their nature. In other words, these interactions are a projection of how humans treat their nature and whether these treatments encourage respect and care for the ecosystems, or encourage ecological destruction. In addition, they give a glance of how humans treat each other, i.e. they mirror humans' social and political relations. Accordingly, fables are considered a rich source for ecolinguistic studies, however, few studies examine a literary discourse, especially fables from an ecolinguistic perspective. 


\section{Shireen Samy Mohamed Ibrahim}

4. Research questions:

The study seeks to answer the following questions:

1) What language patterns does the writer use to explore nature?

2) How do the fables either encourage respect and care for the ecosystems, or encourage ecological destruction?

3) What makes these fables a model for ecolinguistics?

4) To what extent do the fables succeed in portraying human social relations and attitude towards nature?

5. Data sources:

In this paper the researcher analyzes an example of children's literature genre, namely Further Fables for Our Time. It was written in English by James Thurber in 1956. To attain the objectives of the study, the researcher uses corpus linguistics as a research method, compiles her own corpora, depending on LancBox software: Lancaster University corpus toolbox version 4.0. LancBox is a program developed at Lancaster University. The data is comprised of 47 fables written by James Thurber, collected from the internet in pdf form. The researcher downloaded the fables from this site:

https://www.fadedpage.com/showbook.php?pid=20130335

The analysis draws on these tools:

1- KWIC (key words in context) displays words in context or shows a node word within a text like concordance lists. KWIC constitutes the starting point of qualitative analysis.

2- Words that show a list of all the items of a given type in a corpus (e.g. all words, nouns, adjectives, adverbs) and the number of their occurrences, i.e. their frequency lists. These words contribute to quantitative analysis.

6. Review of literature:

In 2014, Alexander and Stibbe define ecolinguistics as follows "ecolinguistics is concerned with how language is involved in forming, maintaining, influencing or destroying relationships between humans, other life forms and the environment" (p.1). The word 'humans' does not refer to humans in general, but to "groups of humans as they are organized into cultures, societies, professions, industries and institutions" (p.2), as each group has its own way of talking about, writing about and perceiving the world. 
Stibbe (2014) writes an article that clarifies the relation between ecolinguistics and critical discourse studies. Ecolinguistics tends to depend on the same forms of linguistic analysis of critical discourse studies. However, while discourse analysis focuses only on the relationship of humans with other humans, ecolinguistics deals with, not only the relationship of humans with other humans, but also the relationship of humans with the larger ecological system that all life depends on. Ecolinguistics criticizes those who encourage ecologically destructive behavior and seeks out those who encourage relationships of respect and care for the natural world. "The expanded context of ecolinguistics complicates power relations between oppressor and oppressed since it considers impacts on non-human subjects and future generations not yet born" (p.117). This requires both the development of the theoretical framework of critical discourse studies, and the development of "an application of an ecologically based normative framework for judging discourses against" (p.117).

One of the most important contributions in the field of ecolinguistics is Stibbe's (2015) book. In this book, he explains what 'the stories we live by' means. He elucidates that the word 'stories' does not refer to the books or novels or short stories that we read to children. Instead, it refers to any type of text, or discourse (written or spoken) that surrounds us, and what is beyond the sentences of this discourse, or how to read between the lines.

For instance, the idea of superiority of human, and the idea that economic growth is great and inevitable are stories established in our mental model. "The stories- we- live- by are, therefore, cognitive structures which influence how multiple people think, talk, and act" (p.10). Then, Stibbe explores the ecosophies he adopts during analyzing the stories he mentioned in the book. He states eight forms that stories take, and their linguistic manifestation, or how these forms are manifested through the language the writers, or the speakers use. The eight forms or ecosophies are ideology, framing, metaphor (a type of framing), evaluation, identity, conviction, erasure, and salience.

Fill (2019) adopts Halliday's point of view about the language and its role for humans, plants, and animals. Halliday (1990) realizes that the language detaches humans from the other living beings. It differentiates between what is useful and unuseful for humans, for instance, herbs are useful, and weeds are unuseful. In addition, some words are reserved for humans only like talk, think, and contemplate. By this way, nature is always passivized or acted upon. 
Poole (2019) tries to widen the framework of corpus linguistics and asserts the importance of corpus linguistics in the ecolinguistic studies. Ecolinguists have been using corpus linguistics to analyze discourses mainly related to ecological issues, e.g. discourses about climate crisis, reports about animals on wildlife. Obviously, research of this kind, which analyzes environmental issues "has yielded important insights into language use" (p.72), and the way we comprehend and perceive the physical world. In addition, Poole, through his paper, underlines the possibility of using corpus-aided approach to reveal the language patterns used throughout any discourse "which normalize and perpetuate a complex of attitudes, identities, practices, and relationships with the physical world" (p.72).

Burke and Copenhaver (2004) discuss fables from an anthropomorphism viewpoint, explores the reasons why the early childhood stories depend on animal with human characteristics, the function of literature, the process of anthropomorphism, and the development of anthropomorphism in children's literature. The article points out that "the lively animals would soften the didactic tone and ease the tensions raised by dealing with issues not yet fully resolved or socially controversial" (p.210). Morals and responsibilities, power versus weakness, personal relationships animal rights, race and social class, ecology, respecting difference, and feminism are all topics that can be discussed through fables or through using animals.

Fields in 2016 published an article. The article includes the analysis of three versions of a fable about dogs and wolves from the Roman imperial era, and illustrates different ways of conceptualizing liberty, and its opposites: physical confinement, dependency, and enslavement to luxury. The article then connects these conceptions of freedom with the hierarchical social, and political environment of the Roman Empire.

By using Aesop's fables and other fables, Fields (2016) represents the relation between wild and domestic animals, and how this resembles human social and political relations. For instance, the tame animals are subject to wild animals, and the wild animals are not only free, but also enjoy this domination. The article displays some stories in which the tame or domestic animals refuse the idea of the dominance of the wild animals, the idea of degradation and hierarchy, and rather maximize the idea or the importance of liberation or freedom.

7. Theoretical Framework:

Lakoff derived his thoughts from Fillmore. The beginning was in 1980, Lakoff and Johnson wrote a book in which they prove the notion 
that "most of our ordinary conceptual system is metaphorical in nature" (p.4). Conceptual metaphors shape the way we think and act. We use metaphors in our daily life unconsciously. They present over 58 different metaphors we use in our life, and explain how we comprehend them.

Lakoff (2004) illustrates four important concepts about frame:

1) Every word evokes a frame.

2) Words defined within a frame evoke the frame.

3) Negating a frame evokes the frame.

4) Evoking a frame reinforces that frame.

Consequently, writers choose their words carefully to trigger, or activate desired frames.

In 2010, Lakoff discusses the idea of environmental hypocognition: the tragedy of the absence of frames in his article entitled "Why it matters how we frame the environment", and states that:

Hypocognition is the lack of ideas we need. We are suffering from massive hypocognition in the case of the environment...The environment frame sees the environment as separate from, and around us. Yet, we are not separate from nature. We are an inseparable part of nature. Yet we separate self from other and conceptualize nature as other (p.76).

\section{Analysis:}

The research draws on one type of ecosophies categorized by Stibbe (2015), i.e. frames, and depends on Lakoff's frame theory in the analysis. To achieve frame analysis, the researcher analyzes the top 30 most frequent nouns, which relate to nature, and traces how they are framed. The frequency of certain words and phrases helps to focus the reader's attention and evokes certain frames about nature.

Table 1.1

The Top 30 Most Frequent Nouns That are Related to Nature in Further Fables for Our Time.

\begin{tabular}{|c|c|c|c|c|c|}
\hline Word & Freq. & Word & Freq. & Word & Freq. \\
\hline Mouse & 47 & Egg & 18 & Rose & 14 \\
\hline Man & 46 & Wood & 17 & Frog & 14 \\
\hline Crow & 41 & Tiger & 17 & Mongoose & 13 \\
\hline Cat & 34 & Hen & 17 & Bird & 13 \\
\hline Fox & 31 & Dove & 16 & Turtle & 13 \\
\hline Phoebe & 26 & Cricket & 16 & Beasts & 12 \\
\hline Bear & 23 & Goose & 16 & Monkey & 12 \\
\hline Moth & 23 & Wolf & 16 & Shore & 12 \\
\hline Sea & 22 & Wren & 14 & Weed & 12 \\
\hline Lion & 20 & Tree & 14 & Bat & 11 \\
\hline
\end{tabular}




\section{Shireen Samy Mohamed Ibrahim}

Mouse: the writer James Thurber frames the mouse as a lazy animal, even at the most important time of the year. In "The truth about Toads", the mouse is boasting being asleep on Christmas Day. In "The foolhardy mouse and the cautious cat", the mouse is framed as an idiot animal, who believes himself a brave hero. He starts bragging this fake tournament. In "The mouse and the money", the mouse is an arrogant and a greedy animal. Thurber conveys these frames via these trigger words and phrases: "not stirring", "foolhardy", "eccentric", "mechanical", "aristocracy", "bragged", "distinction", "live like a king", "rich", "millionaire".

Man: the difference between 'mouse' and 'man' is rather slight in terms of frequency. According to "The bat who got the hell out", and "Oliver and the other ostriches", man is framed as a role model in which all other creatures wish to live like him. Man lives a luxurious life. The writer demonstrates the superiority of man over other species, in "The human being and the dinosaur". Additionally, he shows how man exploits nature, in "The godfather and his godchild", and "Ivory, apes, and people", as man kills animals to satisfy his desires for collecting precious and rare things so as to make a fortune. In "the weaver and worm", Thurber represents the relation between a weaver and silkworm. Although their work complements each other, they scorn each other. In "The lady of the legs", man deceives a frog and praises her just to catch her and make a delicious dish. Thurber conveys these frames via these trigger words and phrases: "live like a man", "men have the best food, and the most fun", "uppercase", "monarch", "the chosen species", "the certain survivor", "I have rhinoceros horn", "moose's antlers", "insulted him", "served", "restaurateur", "bragging".

Crow: the crow is framed as a cocky bird, in "The fox and the crow", as he praises himself. He thinks himself even better than other singing birds. Moreover, he is represented as an idiot when he believed the words of the sly fox, in "Variations on the theme". In another position in the same fable, the crow is framed as a smart bird when he accused the fox of theft when he felt threatened. In "The crow and the scarecrow", the crow is framed as a strong bird. Thurber conveys these frames via these trigger words and phrases: "praising", "unique", "famed", "talented", "scornfully", "haughtily", "criminal", "evidence", culprit", "an armada of crows".

Cat: in "The truth about Toads", the cat is framed as a bad animal who mocks at toad. The cat describes him as an ugly creature and stupid. Through another fable, "The foolhardy mouse and the cautious cat", the cat is portrayed as a cautious animal, who sees himself cannier than a 
mouse. In "The cat in the lifeboat", the cat is framed as a daydreamer who thinks himself unique. By the fable "Two dogs", the author emphasizes that the relation between dogs and cats is just a chase relationship, and they could not be friend. Thurber conveys these frames via these trigger words and phrases: "ugly", "cautious", "did not pounce", "his singularity", "his fantasies", "lost in his daydreams", "egotism", "honors", "medals", "run", "chase", "trailing", "hunt", "catch", "grab".

Fox: the fables "The lion and the foxes", "The fox and the crow", and "Variations on the theme" frame the fox as a deceitful and a greedy animal. He uses some tricks to deceive the lion to take all his share of the prey, deceives the crow to take his food, and mocks at the crow. In "The trial of the old watchdog", the fox is depicted as a notorious fox. Thurber conveys these frames via these trigger words and phrases: "withholding tax", "stag", "penalty", "his share", "cunning", "the lion's share", "scornfully", "notorious red fox".

Phoebe: there are two images of the phoebe. The first image is in "The butterfly, the ladybug, and the phoebe", in which the phoebe is a weird father. Although he is a very responsible father who flies and provides his children with food, he sometimes wishes his house were on fire. The second image is in "The kingfisher and the phoebe", in which the phoebe is a weird mother. Though she is very proud of her sons, she has a very strange wish. She desires to see one of her sons a great singer, greater than the nightingale. The writer conveys these frames via these trigger words and phrases: "provide", "dinner", "guilty", "a remarkable phoebe", "unlike any other phoebe", "ambitious", "a great singer". "insisted".

Bear: in "The truth about toads", the bear is framed as a useful animal for human and other creatures. However, in "The bears and the monkeys", the bears are framed as living in the past, easy to be deceived, and do nothing in their life. In "The grizzly and the gadgets", the bear is depicted as an angry animal. Anything, even the simple one, can stark his anger. Thurber conveys these frames via these trigger words and phrases: "I tell them how deep the winter will be", "prisoners of past-time", "forebears", "their fun and games", "new liberation", "wear a collar", "we save you", "submitted", "angry", “exasperated", “enraged", "growling", "shouting".

Moth: there are two different kinds of moths, in "The clothes moth and the luna moth", in which the clothes moth flatters and admires the luna moth, but he has been exploited. On the other hand, we have the luna moth which is framed as arrogant and deceptive who scorns and exploits the clothes moth to achieve her aim. The trigger words and phrases are 


\section{Shireen Samy Mohamed Ibrahim}

"conceived a great desire for her", "I have to have you", "ardor increased", "it was love at first flutter", "a lovely luna moth", "said the luna moth haughtily", "scorn", "cajole her admirer", "let him believe that".

Sea: sea is portrayed as just a place some animals live in, as in "The sea and the shore". The fable "The cat in the lifeboat" evokes only the ugly face of the ocean. In "The bachelor penguin and the virtuous mate", sea is framed as just a resource for food, or like a place of work. Moreover, sea is depicted as place animals use to hide from an imaginary creature, in "The shore and the sea". The trigger words and phrases are "lived in the sea", "seemed something less satisfying", "hurricane", "SOS", "lifeboat", returning early from the sea", "gone down to the sea to fish", "disappear beneath the waves", "we are saved".

Lion: the lion is represented as the king of beasts who fights for his kingship, in "The tiger who would be king". Also, he is framed as a dishonest animal who wants to take the share of the cow, the goat, and the sheep from the prey under the claim that he is the king, in "The lion and the foxes". According to "The lion and the lizard", the lion is a greedy animal. The trigger words and phrases are "crown", "terrible fight", "defend his crown", "monarch", "king of the beast", "the lion got it all", "he got fatter", "obese".

Egg: the noun 'egg' is mentioned in two fables "Oliver and other ostriches", and "The goose that laid the gilded egg". In the two fables, the ostriches and the goose are boasting their eggs. The trigger phrases are "priceless treasure", "golden egg of lore and legend", "glittering miracle", "we lay the biggest eggs", "the best eggs".

Wood: in "The fox and the crow", and "Variations on the theme", wood appears as just a place the fox runs into to hide. In "The rose, the fountain, and the dove", it is framed as a dangerous and a bleak place, while in "The turtle who conquered time", wood is represented as a home for some animals. The trigger phrases are "trotted away into the woods", "ran for the woods", "slunk away into the woods", "there is nothing in the wood, but horned owls", "lived in a neighboring wood", "back to his tree in the wood".

Tiger: in "The cat in the lifeboat", the tigers are represented as living in gloomy places. In "The tiger who would be king", the tiger is depicted as an ornery animal who wants to take the kingship from the lion. However, in "The tigress and her mate", the tiger is framed as an irresponsible father. The trigger words and phrases are "sombre island inhabited by surly tigers", "I'll be king of beasts", "against the pretender", "fighting", "the struggle", "monarch", "he didn't want to be 
bothered by his young", "if the kids keep me awake by yowling, I'll drown them", "he went away, as all male tigers do".

Hen: the hen is framed as a complaining and self-centered bird, in "The hen party". In "The goose that laid the gilded egg", the hen underestimates the goose's egg. As stated in "What happened to Charles", the hen is a sentimental and a careful bird. The trigger words and phrases are "ailments", "inflamed ego", "many pains", "reciting her complaints", "that is an ordinary goose egg painted yellow", "like any other yellow gosling", "only punier", "a sentimental hen".

Dove: in "The rose, the fountain, and the dove", the dove is depicted as a peaceful, and a nice bird who hates to live in bleak woods. The trigger phrases are "a graceful landing", "I like to fly above the green valley", "the green valley is all I know, and all I want to know", "I like it where I am".

Cricket: in "The cricket and the wren", and "The turtle who conquered time", the cricket is framed as a famous musician. The trigger phrases are "his fame as a fiddler", "an orchestra of crickets played music".

Goose: the fable "The goose that laid the gilded egg" portrays the goose as a rational bird. However, the fable "What happened to Charles" represents the goose as a naive bird. The trigger words and phrases are "did not seem overjoyed", "I don't care what it looks like", "gullible".

Wolf: the fables "The truth about toads", and "The wolf who went places" depict the wolf as a self-centered animal. The trigger phrases are "wolf who thinks he founded Rome", "a wealthy young wolf", "oblivious of everything except himself".

Wren: the fable "The cricket and the wren" frames the wren as a fawning bird who flatters the cricket to win a competition. The trigger words and phrases are "it is a greater honor to be judged by you", "gave the critic a cigar", "handsome", "authoritative".

Tree: in the fables "The fox and the crow", and "Variations on the theme", tree is used as just a place crow sits on. In "The grizzly and the gadgets", and "The chipmunk and his mate", the noun "tree' refers to Christmas tree. Moreover, in "The weaver and the worm", the worm uses a tree as a tool to spin its cocoon. The trigger phrases are "perched in a tree", "to a tree in which sat a crow", "the crow in the tree", "the Christmas tree", "the Christmas tree ornaments", "spinning its cocoon in a white mulberry tree".

Rose: in "The rose and the weed", the rose is boasting her beauty. On the other hand, in "The rose, the fountain, and the dove", the rose is framed as a rebellious rose who wishes to change its natural 


\section{Shireen Samy Mohamed Ibrahim}

characteristics. The trigger words and phrases are "haughtily", "silverweed", "jewelweed", "candyweed", "her pretty petals", "I wish I were root loose and fancy-free, like the dove", "complained the rose", "sighed the rose".

Frog: the fable "The lady of the legs" represents the frog as a conceited animal who is bragging with her beauty. In "The turtle who conquered time", the frog is presented as a tool that produces sounds. The trigger words and phrases are "prettiest eyes", "the finest voice", "wonderful", "took every superlative for praise", "the barker", "he composed an impressive spiel".

Mongoose: in "The peace like mongoose", the mongoose is framed as a peaceful, and an intellectual animal who refuses to kill copra. The trigger phrases are "didn't want to fight cobra", "intellectually curious", "against the ideals and traditions of mongoosism".

Bird: in "The bluebird and his brother", there are two brothers who are completely different. One is framed as a happy bird, while the other is framed as a sad one. The bird is depicted as a rebellious bird who wants to be rich, in "the magpie's treasure", while the bird is a co-operative bird, in "What happened to Charles", and "The turtle who conquered time". The trigger words and phrases are "glad bird", "sad bird", "lucky", "sorry", "happy", "gloomy", "I wanted rings from the time I could fly", "my parents were worm collectors", "a wealthy bird", "all the birds set about building a memorial".

Turtle: the fable "Two dogs" portrays the turtle as an example of slowness. The fable "The turtle who conquered time" shows one of the natural characteristics of turtles, i.e. turtles live a very long life. The trigger words and phrases are "we couldn't catch a turtle this way", "slow", "the oldest of all living creatures", "the ancient turtle", "this remarkable turtle is a direct descendant".

Beasts: the fables "The lion and the foxes", and "The tiger who would be king" depict the beasts as animals who live in their own kingdom and have their own king. The fable "What happened to Charles" frames the beasts as co-operative animals. The trigger phrases are "I am king of beasts", "greet the king of beasts", "beasts set about building a memorial".

Monkey: through the fable "The bears and the monkeys", the monkey is depicted as a glibber and a commanding animal who wants to control the bears. The trigger words and phrases are "fast-talking", "glib", "glibber than the glibbest monkey", "we have come to liberate you", "now you are free to do what I tell you to do", "we save you from the dangers of choice". 
Shore: in the fables "The sea and the shore", and "The shore and the sea", shore is depicted as just a place without indicating anything special about it. For some creature, it is just a land. In "The cat in the lifeboat", it is framed as a sullen shore. The trigger phrases are "became the discoverers of land", "the sullen shore".

Weed: in "The rose and the weed", the weed appears as a useless and a distasteful plant, who tries to defend himself. The trigger words and phrases are "economically useless", "unsightly of appearance", "bladderweed", "beggarweed", "anywhere you can grow I can grow better".

Bat: according to "The bat who got the hell out", the bat is a discontented and a rebellious bird. He sees the bat's colony as a hell. The trigger phrases are "the discontented young bat quit the bat colony", "flickered out of the cave".

\section{Discussion and Conclusion:}

From the above analysis of frames, it is obvious that, in very few positions, animals and birds are depicted as peaceful, or wise. The frames state that the dominant traits of the animals are being deceptive, rebellious, and arrogant by using trigger words and phrases which assert these traits. These traits reflect the characteristics of modern age, and the attributes of modern man. In almost all the fables animals try to exploit and control other animals. This is what humans do, as well. They raise animals to take advantage of and control them, in addition to the exploitation of other humans, and trying to impose control over them. Furthermore, the writer is keen to point out the superiority of man over other species in different aspects.

Elements of nature, e.g. sea, shore, rose, and tree do not get any especial frames. Their beauty and importance are not highlighted. The author uses them for stylistic purposes. He focuses only on how different species use or treat these elements of nature. This is another way to mirror the features of modern man. He became uninterested in noticing the beauty of nature, and all his goal is how to take advantage of its elements.

According to corpus analysis, we notice that the fables comprise different kinds of animals, birds, and elements of nature. They are very close in terms of frequency, some of them are even equal. The only animal that is mentioned more frequent than man is the mouse. Mouse is one of the weakest and smallest animals in the animal kingdom. Moreover, he is represented as a foolish animal, and a fictitious hero, 


\section{Shireen Samy Mohamed Ibrahim}

although mice were widely represented in folktales and old fables as helpers, and powerful animals that are benign towards human. This poor image of mouse can be considered as an indirect way or another way of confirming the supremacy of man over all other species.

Frame analysis depends mainly on the technique of repetition of certain nouns to evoke certain frames in the two fables. It turns out that the majority of frames are not portraying the animals or the elements of nature good. the dominant tendency is that which stimulates nature exploitation. 


\section{References}

Alexander, R. \& Stibbe, A. (2014). From the analysis of ecological discourse to the ecological analysis of discourse. Language Sciences, 41, pp.104-110, doi: 10.1016/j.langsci.2013.08.011.

Bolongaro, E. (2009). Calvino's encounter with the animal: Anthropomorphism, cognition and ethics in Palomar. Quaderni d'italianistica, $\quad x x x: 2, \quad$ pp.105-128. Retrieved from https://jps.library.utoronto.ca/index.php/qua/article/download/11905/114 $\underline{0}$

Bowker, L. \& Pearson, J. (2002). Working with specialized language: A practical guide to using corpora. London: Routledge.

Burke, C.L. \& Copenhaver, J.G. (2004). Animal as people in children's literature. Language Arts, 81:3, pp.205-212.

Ecolinguistics. (n.d.). Retrieved from https://ipfs.io/ipfs/QmXoypizjW3WknFiJnKLwHCnL72vedxjQkDDP1 mXWo6uco/wiki/Ecolinguistics.html

Fields, D. (2016). Chained animals and human liberty. Classical World, $110: 1$, pp.61-86.

Fill, A. (1997). Ecolinguistics as European idea. The European Legacy, 2:3, pp.450-455, doi: 10.1080/10848779708579756.

Fill, A. (2019, August). Using language to achieve 'con-vironmental' awareness (Paper presentation). The Fourth International Conference on Ecolinguistics (ICE), Odense, Denmark.

Fill, A. \& Muhlhausler, P. (Eds.). (2001). The ecolinguistics reader: Language, ecology and environment. London: Continuum.

Halliday, M.A.K. (1990). New ways of meaning: The challenge to applied linguistics. In: Fill, A. \& Muhlhausler, P. (Eds.). (2001). The ecolinguistics reader: Language, ecology and environment. London: Continuum, pp.175-202 (Reprint of Halliday, 1990).

Haugen, E. (1972). The ecology of language. In: Fill, A. \& Muhlhausler, P. (Eds.). (2001). The ecolinguistics reader: Language, ecology and environment. London: Continuum, pp.57-66 (Reprint of Haugen, 1972).

Lakoff, G. (2004). Don't think of an elephant!: Know your values and frame the debate: The essential guide for progressives. White River Junction, VT: Chelsea Green.

Lakoff, G. (2010). Why it matters how we frame the environment. Environmental Communication, 4:1, pp.70-81, doi:10.1080.17524030903529749.

Lakoff, G. \& Johnson, M. (1980). Metaphors we live by. Chicago: University of Chicago press.

McEnery, T. \& Hardie, A. (2012). Corpus linguistics: Method, theory and practice. United Kingdom: Cambridge. 


\section{Shireen Samy Mohamed Ibrahim}

Poole, R. (2019, August). Expanding the scope of corpus-aided ecolinguistics (paper presentation). The Fourth International Conference on Ecolinguistics (ICE), Odense, Denmark.

Steffensen, S. \& Fill, A. (2014). Ecolinguistics: The state of the art and future horizons. Language Sciences, 41, pp.6-25.

Stibbe, A. (2014). An ecolinguistic approach to critical discourse studies. Critical Discourse Studies, 11:1, pp.117-128

Stibbe, A. (2015). Ecolinguistics: Language, ecology and the stories we live by. London: Routledge.

Surber, K. (n.d.). 10th Grade English: Help and review:Who is Aesop? biography, fables \& morals.ch.9, lesson13. Retrieved from https://study.com/academy/topic/ancient-literature-for-10th-grade-helpand-review.html

Thurber, J. (1956). Further fables for our time. London: Hamish Hamilton Ltd.

$\mathrm{Wu}, \mathrm{Y}$. (2018). Ecological discourse analysis. Advances in social science, education and humanities research, 181. Atlantis Press. 